Received 13.12.2013 Reviewed 20.01.2014 Accepted 10.02.2014

A - study design

B - data collection

C - statistical analysis

D - data interpretation

$\mathbf{E}$ - manuscript preparation

F - literature search

\section{Comparison of shallow foundation design using Eurocode 7 and Polish Standard}

Andrzej OLCHAWA ${ }^{\text {1) ABDEF }}$, Andrzej ZAWALSKI ${ }^{2)}$ ABDEF

\footnotetext{
1) University of Technology and Life Sciences, Department of Geotechnics, al. prof. S. Kaliskiego 7, 85-789 Bydgoszcz, Poland; tel. +48 52 340-84-08, e-mail: andyolchawa@wp.pl

${ }^{2)}$ University of Technology and Life Sciences, Department of Geotechnics, al. prof. S. Kaliskiego 7, 85-789 Bydgoszcz, Poland; tel. +4852 340-84-07, e-mail: zawalski@utp.edu.pl
}

For citation: Olchawa A., Zawalski A. 2014. Comparison of shallow foundation design using Eurocode 7 and Polish Standard. Journal of Water and Land Development. No. 20 p. 57-62.

\begin{abstract}
Bearing capacity of cohesive soils was calculated based on PN-B-03020:1981P and Eurocode 7. Strength parameters of cohesive soil modified by the authors: shear strength in undrained conditions $c_{u}$, effective cohesion $c^{\prime}$ and effective friction angle $\phi^{\prime}$ were adopted for calculations acc. to Eurocode 7 . Values of these parameters depend on a leading parameter - liquidity index $I_{L}$.

Bearing capacity was calculated for two pad foundations of a size $B \times L=2.0 \times 3.0 \mathrm{~m}$ and $1.5 \times 2.0 \mathrm{~m}$ and for one $2.0 \times 14.0 \mathrm{~m}$ strip foundation. The capacity calculated acc. to EC 7 was reduced by multiplying by a factor $\alpha=0.87$ to account for different bearing capacity coefficients in Polish Norms and Eurocodes. Performed calculations showed comparable bearing capacity of substratum irrespective of adopted norms EC 7 and PN for foundation pads. In all analysed cases, however, the bearing capacity of foundation strips calculated acc. to Eurocode 7 was higher than those calculated acc. to PN-B-03020:1981P. The reason is in the values and ways of accounting partial security coefficients and in differences in the values of shape coefficients used in the equation for ultimate bearing resistance of soil substratum.
\end{abstract}

Key words: bearing resistance, cohesive soils, Eurocode 7, geotechnical design, shallow foundations

\section{INTRODUCTION}

Long observations of constructions did not show damages or disasters associated with designing foundations based on Polish Standard - PN-B-03020: 1981P [WYSOKIŃSKI 2005]. Hence, it is justified to assume that safe foundation of a construction is provided when the value of bearing resistance calculated acc. to PN-EN 1997-1 is comparable with that calculated acc. to PN-B-03020:1981P.

Coming from such assumptions the authors calculated bearing capacity of soils acc. to PN-B03020:1981P and to Eurocode 7 (EC 7). For calculations acc. to EC 7, soil parameters were taken from available literature [KOSTRZEWSKI 1980; PISARCZYK, RYMSZA 1993].

Comparative analysis of bearing capacity of soils calculated acc. to both norms showed that they are insufficiently comparable [OLCHAWA, ZAWALSKI 2014]. Therefore, an attempt has been undertaken to correct shear strength parameters of cohesive soils $\phi^{\prime}, c^{\prime}$ and $c_{u}$. Modification consisted in selecting parameters in such a way that bearing capacity of soils calculated acc., to EC 7 would be comparable with that calculated acc. to PN-B-03020:1981P.

The purpose of this paper is to propose shear strength parameters of cohesive soils to be used for computing ultimate bearing resistance according to Eurocode 7. The proposed nomographs can be used 
for foundation design of Geotechnical Category 1 structures as well as some types of Geotechnical Category 2 (e.g. residential buildings with uncomplicated ground conditions).

Difficulties in Eurocode 7 implementation for practical foundation design in Poland was discussed by GosK [2010], KŁosIŃSKI [2013], KOTLICKI [2005; 2009], SULEWSKA and KONOPKA [2013].

\section{METHODS OF CALCULATION}

The norm PN-EN 1997-1:2008P Eurocode 7 estimates that the ultimate limit state ULS will be fulfilled if:

$$
V_{d} \leq R_{d}
$$

where:

$V_{d}$ - design value of vertical load acting normal to the foundation base,

$R_{d}$ - design value of the resistance to an action.

Bearing resistance is calculated acc. to Eurocode 7 in drained conditions (long-term design situation) and additionally in undrained conditions (short-term design situation)

According to PN-B-03020:1981P, checking the ultimate limit state of bearing capacity consists in the comparison of the vertical component of computational bearing resistance of soil substratum $Q_{f N B}$ and computational vertical component of load $N_{r}$ acc. to equation:

$$
N_{r} \leq m Q_{f N B}
$$

where:

$m$ - correction factor dependent on the method of calculation of bearing capacity and estimation of geotechnical parameters.

In Eurocode 7, partial coefficients are used for interactions of soil and resistance parameters.

In the Country Appendix PN-EN 1997-1:2008/ NA:2011P point N.A.2.6, computational approach DA2* is recommended as a design method. In this approach, computational value of interaction, dealt with as unfavourable, is estimated using coefficient 1.35 for constant loads and 1.50 for variable loads. Computational value of ultimate bearing resistance is calculated based on characteristic geotechnical soil parameters and then the obtained value is divided by 1.4. The problems concerning design approaches in Eurocode 7 were discussed by GALAS, KIZIEWICZ [2009], GARWACKA-PIÓRKOWSKA [2011], KUCHLER, KUSZYK [2006], VOGT et al. [2006].

In PN-B-03020:1981P, presented method is based on static computational estimates of soil parameters and loads acting on a construction. Estimation of these values is accomplished by introducing the probabilistic safety margin in a form of load coefficient $\gamma_{f}$ and material coefficient $\gamma_{m}$.
Calculations of the bearing capacity of soil were made for pad foundations of sizes $B=2 \mathrm{~m}$ and $L=3 \mathrm{~m}$ and $B=1.5 \mathrm{~m}$ and $L=2.0 \mathrm{~m}$ and for strip foundation of a size of $B \times L=2.0 \times 14.0 \mathrm{~m}$ at a depth $D=1.0 \mathrm{~m}$.

It was assumed that there is a layer of cohesive soil of liquidity index, $I_{L}=0.15$ or of $I_{L}=0.42$ and of a thickness $h>2 B$ directly under foundations.

To calculate soil bearing resistance acc. to PN-B03020:1981P, characteristic shear strength parameters were adopted from nomographs given in the norm. Polish Norm distinguishes four types of soils marked A, B, C and D: A - over-consolidated moraine soils, B - over-consolidated soils and moraine normally consolidated soils, D - clays of $I_{P}>30 \%$, regardless of origin.

To calculate bearing resistance acc. to Eurocode 7 , characteristic shear strength parameters $-\phi^{\prime}, c^{\prime}$ and $c_{u}$ were adopted from nomographs in Figures 1, 2 and 3 . Values of these parameters are corrected compared to those given in PISARCZYK, RYMSZA [1993] and KOSTRZEWSKI [1980]. The characteristic values of undrained cohesion $c_{u}$ was calculated based on the values of shear strength of Pleistocen soils $\tau_{f}$ [KOSTRZEWSKI 1980], and correction factor $\mu$. The $\mu$ depends on plasticity index, $I_{P}$ [Azzouz et al. 1983].

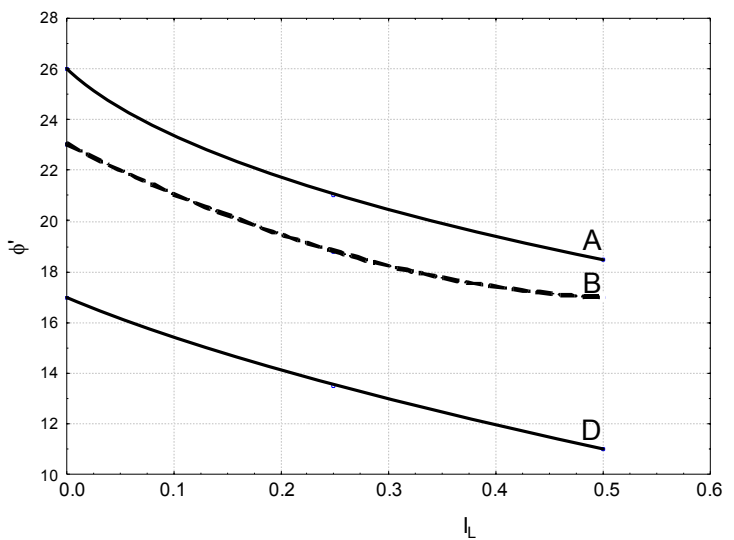

Fig. 1. Proposed effective friction angle $\phi$ ' vs. liquidity index for ultimate bearing resistance calculation acc. to Eurocode 7; source: own study

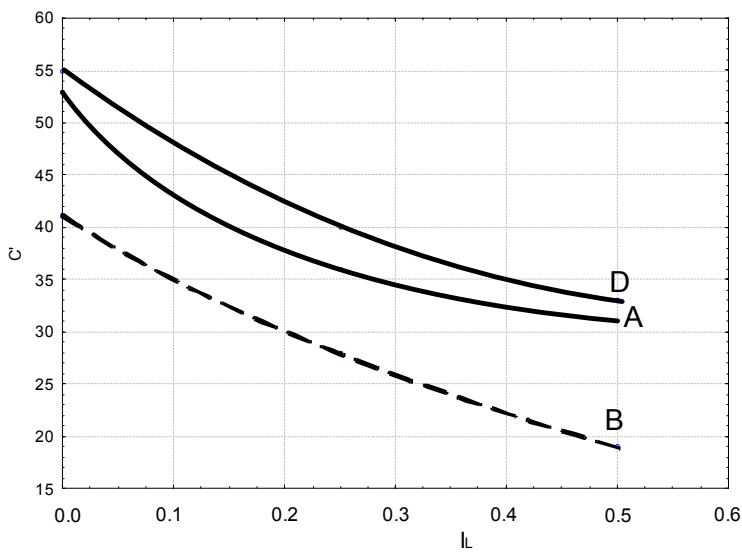

Fig. 2. Proposed effective cohesion $c$ 'vs. liquidity index for ultimate bearing resistance calculation acc. to Eurocode 7; source: own study 


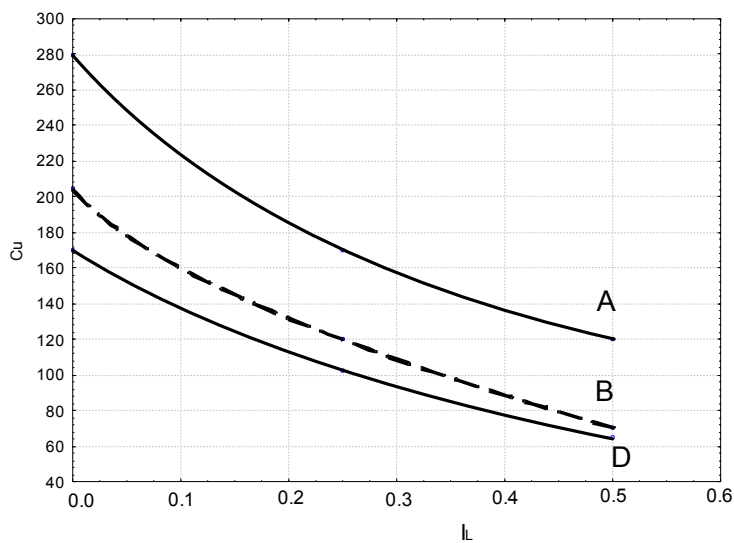

Fig. 3. Proposed undrained shear strength $c_{u}$ vs. liquidity index for ultimate bearing resistance calculation acc. to Eurocode 7; source: own study
To compare the resistance for pad and strip foundations calculated acc. to PN-B-03020:1981P and PNEN 1997-1, a reduction coefficient $\alpha=0.87$ was introduced to account for higher load coefficients used in PN-EN 1997-1:2008 [WYSOKIŃSKI et al. 2011].

Bearing resistance was calculated for 3 types of soils $-\mathrm{A}, \mathrm{B}$ and D. Parameters $\phi^{\prime}, c^{\prime}$ and $c_{u}$ corresponding to soils of the liquidity index $I_{L}=0.15$ or 0.42 were adopted for calculations. Soil resistance parameters used in calculations are set up in Table 1.

\section{ANALYSIS OF COMPUTATIONAL RESULTS}

Results of performed calculations are set up in Tables 2-3. Figure 4 present a comparison of calculated values of ultimate bearing resistance calculated acc. to Eurocode 7 and PN-B-03020: 1981P.

Table 1. Proposed characteristic parameters used for computing ultimate bearing resistance

\begin{tabular}{|c|c|c|c|c|c|c|c|c|c|c|}
\hline \multirow{3}{*}{$\begin{array}{c}\text { Class of } \\
\text { soil }\end{array}$} & \multicolumn{10}{|c|}{ Liquidity index $I_{L}$} \\
\hline & \multicolumn{2}{|c|}{0.15} & \multicolumn{2}{|c|}{0.42} & \multicolumn{2}{|c|}{0.15} & \multicolumn{2}{|c|}{0.42} & \multirow{2}{*}{$\begin{array}{c}0.15 \\
c_{u} \\
\mathrm{kPa}\end{array}$} & \multirow{2}{*}{$\begin{array}{c}0.42 \\
c_{u} \\
\mathrm{kPa}\end{array}$} \\
\hline & $\begin{array}{c}\varphi_{u}^{*} \\
\circ\end{array}$ & $\begin{array}{c}c_{u}^{*} \\
\mathrm{kPa}\end{array}$ & $\begin{array}{c}\varphi_{u}^{*} \\
\circ\end{array}$ & $\begin{array}{c}c_{u}^{*} \\
\mathrm{kPa}\end{array}$ & $\varphi$, & $\begin{array}{c}c^{\prime} \\
\mathrm{kPa}\end{array}$ & $\varphi^{\prime}$ & $\begin{array}{c}c^{\prime} \\
\mathrm{kPa}\end{array}$ & & \\
\hline $\mathrm{A}$ & 22.4 & 41.7 & 17.7 & 30.5 & 22.5 & 40.0 & 19.5 & 32.0 & 205 & 135 \\
\hline $\mathrm{B}$ & 19.2 & 33.4 & 14.2 & 24.1 & 20.5 & 32.0 & 17.5 & 22.0 & 145 & 84 \\
\hline $\mathrm{D}$ & 11.0 & 51.7 & 7.4 & 38.7 & 15.0 & 45.0 & 12.0 & 35.0 & 125 & 78 \\
\hline
\end{tabular}

* Acc. to PN-B-03020:1981P (asterisk is given to distinguish the values of shear strength in undrained conditions $c_{u}$. Source: own study.

Table 2. Bearing resistance calculated acc. to PN-B-03020: $1981 \mathrm{P}$ and Eurocode 7 for soils of $I_{L}=0.15$ and $I_{L}=0.42$ for long-term design situation

\begin{tabular}{|c|c|c|c|c|c|c|}
\hline \multirow{4}{*}{$B \times L$} & \multicolumn{3}{|c|}{ PN-B-03020:1981P } & \multicolumn{3}{|c|}{ PN-EN 1997-1:2008P } \\
\hline & \multicolumn{3}{|c|}{$0.9 m Q_{f N B}(\mathrm{kN})^{*}$} & \multicolumn{3}{|c|}{$\alpha R_{d}(\mathrm{kN}) *$} \\
\hline & \multicolumn{6}{|c|}{ Genetic type of soil } \\
\hline & A & B & $\mathrm{D}$ & A & B & $\mathrm{D}$ \\
\hline \multicolumn{7}{|c|}{$I_{L}=0.15$} \\
\hline $1.5 \times 2$ & 2360.4 & 1630.2 & 1387.1 & 2213.3 & 1579.0 & 1363.3 \\
\hline $2.0 \times 3.0 \mathrm{~m}$ & 4642.4 & 3197.7 & 2708.1 & 4367.4 & 3120.7 & 2681.3 \\
\hline $2.0 \times 14$ & 1191.0 & 809.7 & 708.0 & 1227.9 & 886.1 & 772.0 \\
\hline \multicolumn{7}{|c|}{$I_{L}=0.42$} \\
\hline $1.5 \times 2.0 \mathrm{~m}$ & 1387.2 & 941.0 & 902.0 & 1344.2 & 938.7 & 892.6 \\
\hline $2.0 \times 3.0 \mathrm{~m}$ & 2715.7 & 1835.6 & 1757.0 & 2652.6 & 1859.2 & 1757.4 \\
\hline $2.0 \times 14.0 \mathrm{~m}$ & 682.9 & 454.4 & 453.9 & 757.9 & 536.2 & 512.4 \\
\hline
\end{tabular}

* Strip foundation $\left(\mathrm{kN} \cdot \mathrm{m}^{-1}\right)$.

Source: own study.

In all analysed cases the values of ultimate bearing capacity for pad foundations calculated acc. to Eurocode 7 and PN-B-03020:1981P were comparable. The ratio of respective values was from 0.94 to 1.01 for long-term computational situation and from 0.97 to 1.09 for short-term computational situation. Conditions for the long-term situation are decisive for bearing capacity of the soil.

Ultimate bearing capacity for strip foundations calculated acc. to Eurocode 7 was in all cases higher than that calculated acc. to PN-B-03020:1981P. The ratio was from 1.03 to 1.18 for long-term situation
Table 3. Bearing resistance calculated acc. to PN-B-03020: $1981 \mathrm{P}$ and Eurocode 7 for soils of $I_{L}=0.15$ and $I_{L}=0.42$ for short-term design situation

\begin{tabular}{|c|c|c|c|c|c|c|}
\hline \multirow{4}{*}{$B \times L$} & \multicolumn{3}{|c|}{ PN-B-03020:1981P } & \multicolumn{3}{|c|}{ PN-EN 1997-1:2008P } \\
\hline & \multicolumn{3}{|c|}{$0.9 m Q_{f N B}[\mathrm{kN}]^{*}$} & \multicolumn{3}{|c|}{$\alpha R_{d}[\mathrm{kN}]^{*}$} \\
\hline & \multicolumn{6}{|c|}{ Genetic type of soil } \\
\hline & A & B & $\mathrm{D}$ & A & B & $\mathrm{D}$ \\
\hline \multicolumn{7}{|c|}{$I_{L}=0.15$} \\
\hline $1.5 \times 2.0 \mathrm{~m}$ & 2360.4 & 1630.2 & 1387.1 & 2298.9 & 1630.6 & 1416.4 \\
\hline $2.0 \times 3.0 \mathrm{~m}$ & 4642.4 & 3197.7 & 2708.1 & 4510.0 & 3250.4 & 2793.6 \\
\hline $2.0 \times 14.0 \mathrm{~m}$ & 1191.0 & 809.7 & 708.0 & 1373.5 & 985.7 & 847.6 \\
\hline \multicolumn{7}{|c|}{$I_{L}=0.42$} \\
\hline $1.5 \times 2.0 \mathrm{~m}$ & 1387.2 & 941.0 & 902.0 & 1526.1 & 964.8 & 899.0 \\
\hline $2.0 \times 3.0 \mathrm{~m}$ & 2715.7 & 1835.6 & 1757.0 & 3011.0 & 1903.0 & 1772.2 \\
\hline $2.0 \times 14.0 \mathrm{~m}$ & 682.9 & 454.4 & 453.9 & 913.3 & 578.2 & 538.8 \\
\hline
\end{tabular}

* Strip foundation $\left(\mathrm{kN} \cdot \mathrm{m}^{-1}\right)$.

Source: own study.

and from 1.15 to 1.33 for short-term situation. As in the case of pad foundations, the conditions for longterm situation are decisive for bearing capacity of the soil. Significant differences in the values for strip foundations calculated acc. to both norms resulted from the values of adopted shape coefficients.

Figure 5 show the relationship between shape coefficient and the width to length ratio of the foundation and the internal friction angle $\phi^{\prime}$. Presented graphs indicate that the proportions of shape coefficients calculated acc. to PN and EC 7 depend on the $B: L$ ratio. 
a)

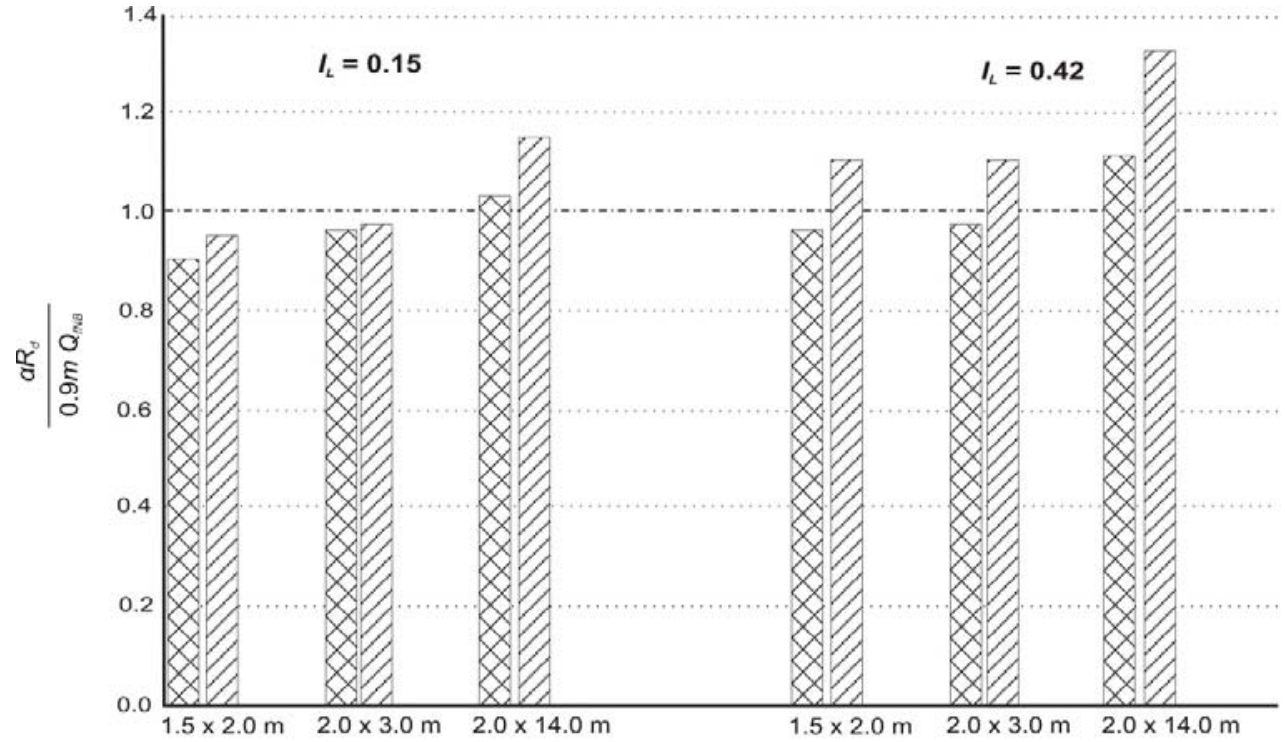

b)

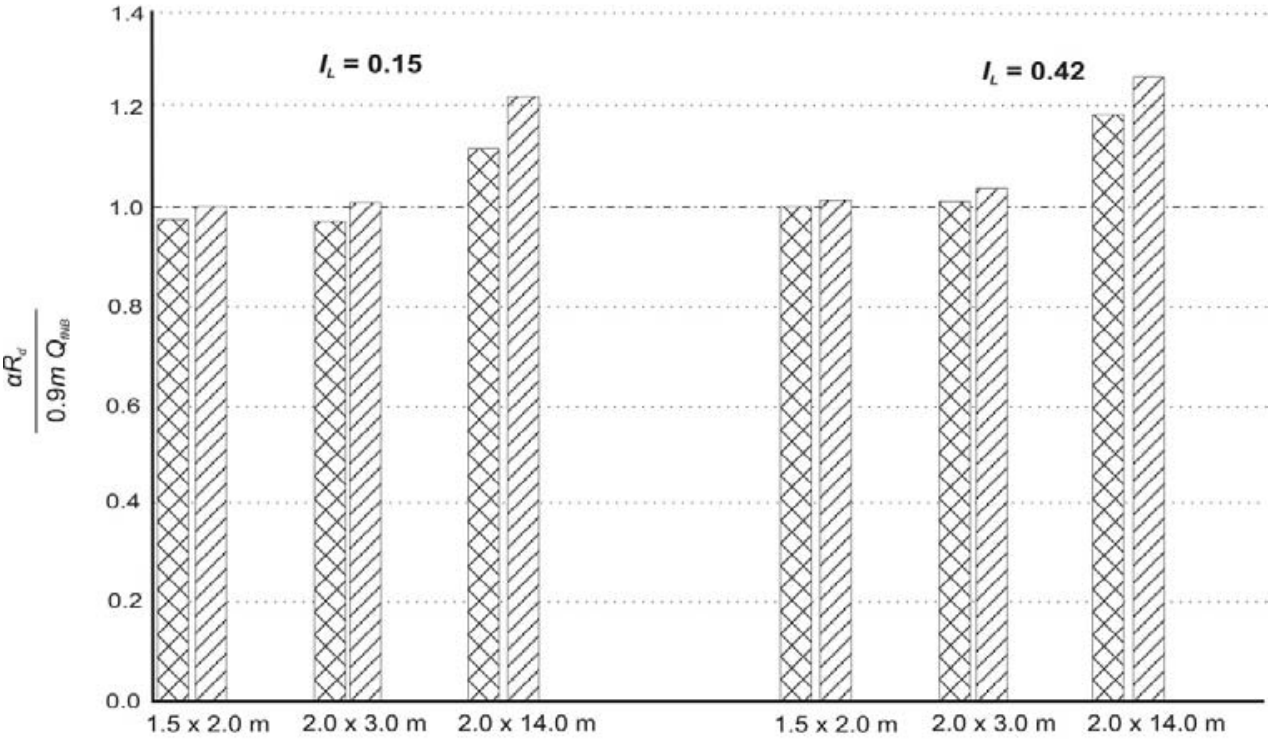

c)

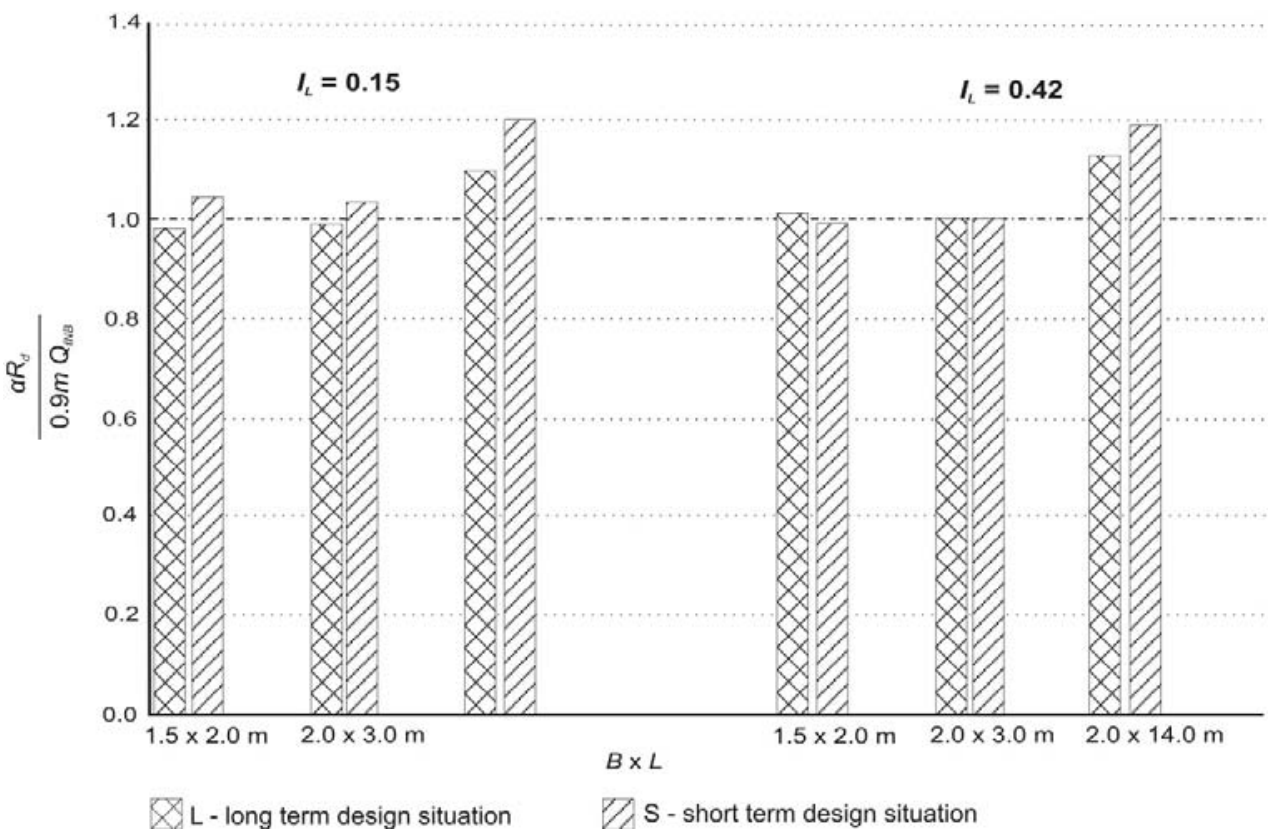

Fig. 4. Comparison of the values of bearing resistance of soil calculated acc. to Eurocode 7 and Polish Norm: a) soils of the type A, b) soils of the type B, c) soils of the type D; source: own study 


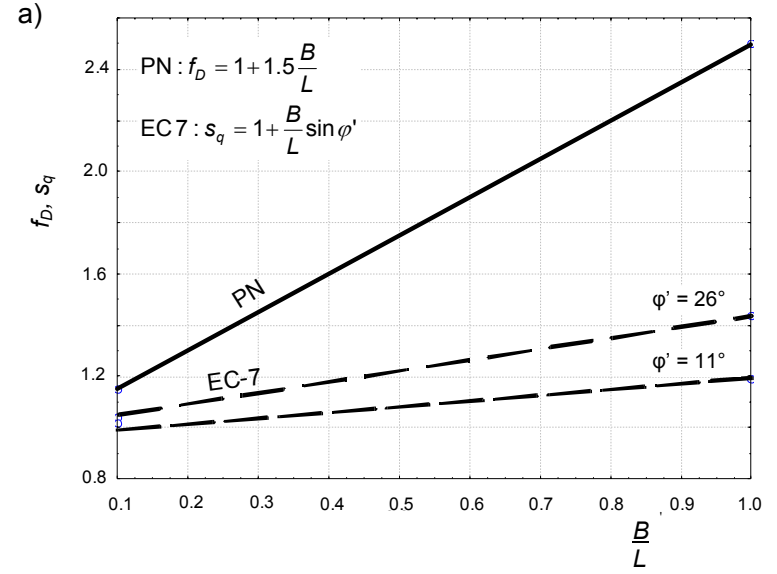

b)

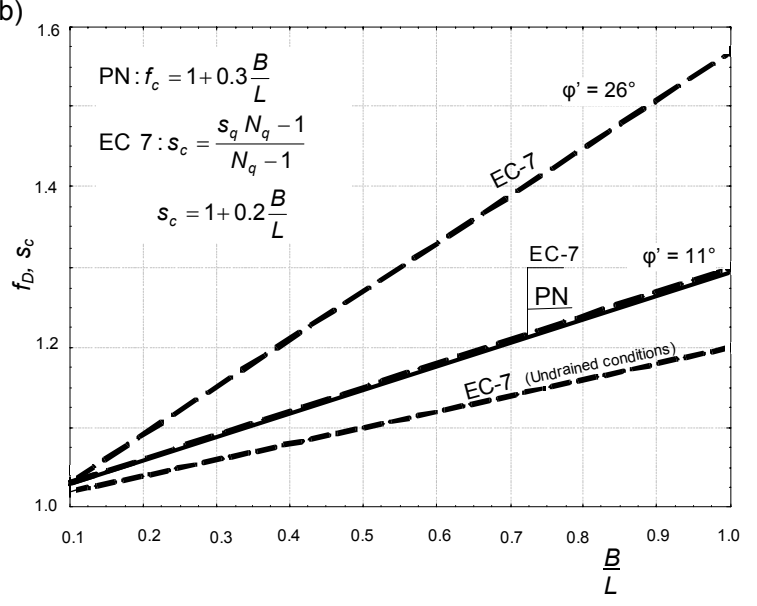

Rys. 5. Shape coefficient values: a) $f_{D}$ and $s_{q}$, b) $f_{c}$ and $s_{c}$ in relation to the foundation width to length ratio used in both norms; source: own study

Assuming the correctness of adopted geotechnical parameters of the soil and shape coefficients from EC 7, the comparability of bearing capacities of pad foundations calculated acc. to both norms may indicate that safety margin drawn from PN-B-03020: $1981 \mathrm{P}$ for strip foundations is too large.

\section{CONCLUSIONS}

1. Presented modification of soil geotechnical parameters known from the literature enables their use in calculations of bearing resistance of soils acc. to Eurocode 7 and to obtain results comparable with those calculated acc. to PN-B-03020:1981P.

2. Bearing capacities of pad foundations calculated acc. to EC 7 and PN-B-03020:1981P are comparable.

3. Bearing capacities of strip foundations calculated acc. to EC 7 were in all analysed cases larger than those calculated acc. to PN-B-03020:1981P.

4. Presented proposal is based on a low number of cases and it is recommended to perform further analyses on more cases.

\section{REFERENCES}

AzzouZ A.S., BALigh M.M., LADD C.C. 1983. Corrected field vane strength for embankment design. Journal of Geotechnical Engineering. Vol. 109. Iss. 5 p. 730-734.

Galas P., Kiziewicz D. 2009. Ocena nośności podłoża pod stopa fundamentową według Eurokodu 7 oraz PN-81/B03020. W: Problemy geotechniczne i środowiskowe $\mathrm{z}$ uwzględnieniem podłoży ekspansywnych [The bearing capacity evaluation of pad foundation based on Eurocode 7 and PN-81/B-03020. In: Expansive soils and their influence on geotechnical properties of subsoil and environmental conditions]. Materiały XV Krajowej Konferencji Mechaniki Gruntów i Inżynierii Geotechnicznej. Bydgoszcz 7-10.07.2009. Bydgoszcz. Wydaw. Uczeln. UTP p. $575-582$.

GARWACKA-PIÓRKOWSKA S. 2011. Porównanie obliczeniowych nośności jednostkowych gruntów pod ławami i stopami fundamentowymi według PN-EN 1997-1 i PN-B03020:1981 [The comparison of computational unit load capacity of grounds under concrete strip footing and spot footing according to PN-EN 1997-1 and PN-B-03020: 1981]. Inżynieria i Budownictwo. $\mathrm{Nr}$ 1. Warszawa. PZITB p. 17-21.

Gosk W. 2010. Nośność podłoża gruntowego pod ławą fundamentową według Eurokodu 7 oraz PN-81/B-03020 [The bearing capacity of subsoil under continuous foundation based on Eurocode 7 and PN-81/B-03020]. Budownictwo i Inżynieria Środowiska. Vol. 1. Nr 2 p. 127130.

GraBOwSKA-OlszewSKA B. (ed.) 1990. Metody badań gruntów spoistych [Methods for determining properties of clayey soils]. Warszawa. Wydaw. Geol. ISBN 83-2200315-3 pp. 387.

KiZIEWICZ D. 2009. Analiza nośności podłoża z gruntów spoistych obciążonego mimośrodowo fundamentem bezpośrednim wg Eurokodu 7 - rozwiązanie przykładu 2.2 ETC10 [Bearing capacity analysis of cohesive soils subjected to inclined load from shallow foundation according to Eurocode 7 - solution of design example 2.2 ETC 10]. Przegląd Naukowy Inżynieria i Kształtowanie Środowiska. Vol. 18(4). Nr 46 p. 67-76.

KŁOSIŃSKI B. 2013. Ocena i przyszłość Eurokodu 7 „Projektowanie geotechniczne" [Evaluation and future of the Eurocode 7 - Geotechnical design]. Przegląd Naukowy Inżynieria i Kształtowanie Środowiska. Vol. 22(2). Nr 60 p. 222-235.

KostRZEWSKI W. 1980. Mechanika gruntów. Parametry geotechniczne gruntów budowlanych oraz metody ich wyznaczania [Soil mechanics. Geotechnical parameters and methods of testing]. Warszawa. PWN. ISBN 8301020 44X pp. 284.

KoTLICKI W. 2005. Projektowanie posadowień bezpośrednich w ujęciu Eurokodu 7 [Design of shallow foundation according to Eurocode 7]. XX Ogólnopolska Konferencja Warsztat Pracy Projektanta Konstrukcji, Wisła - Ustroń. Kraków. PZITB p. 71-90.

KotLICKI W. 2009. Projektowanie posadowień bezpośrednich w EC 7 [Design of shallow foundation according in EC 7]. XXIV Ogólnopolska Konferencja Warsztat Pracy Projektanta Konstrukcji. Wisła. Kraków. PZITB p. 205-245.

KUCHLER A., KuSZYK R. 2006. Posadowienie bezpośrednie w ujęciu EN 1997-1 Eurocode 7 [New method of foundation analysis according to EN 1997-1 Eurocode 7]. Inżynieria i Budownictwo. Nr 12. Warszawa. PZITB p. 661663. 
Olchawa A., ZawalsKi A. 2014. Uwagi na temat parametrów wytrzymałościowych gruntów spoistych do obliczeń nośności podłoża gruntowego według Eurokodu 7 [Some remarks on the shear strength parameters of cohesive soils to be used for computing bearing capacity according acc. to Eurocode 7]. Inżynieria Morska i Geotechnika. In print.

PIECZYRAK J. 2006. Nośność graniczna podłoża gruntowego według PN-81/B-03020 i Eurokodu 7 [Ultimate bearing capacity of subsoil according to Polish Standard PN81/B-03020 and Eurocode 7]. XIV Krajowa Konferencja Mechaniki Gruntów i Inżynierii Geotechnicznej, Białystok - Augustów. Zeszyty Naukowe Politechniki Białostockiej - Budownictwo. Vol. 28(2) p. 197-211.

PISARCZYK S., RYMSZA B. 1993. Badania laboratoryjne i polowe gruntów [Laboratory and field testing of soil]. Warszawa. Ofic. Wydaw. PW pp. 489.

PN-EN 1997-1:2008P, PN-EN 1997-1:2008/NA:2011P. Projektowanie geotechniczne - część 1: Zasady ogólne. [Geotechnical design - Part 1: General rules].

PN-B-03020:1981P. Posadowienie bezpośrednie budowli. Obliczenia statyczne i projektowanie [Building soils. Foundation bases. Static calculation and design].
SulewSKa M., KonoPKa R. 2013. Analiza nośności granicznej podłoża pod stopą fundamentową według PN-EN 1997-1 (2008) i PN-81/B-03020 (1981) [Assessment of bearing capacity of pad foundation based on PN-EN 1997-1 (2008) and PN-81/B-03020 (1981)]. Przegląd Naukowy Inżynieria i Kształtowanie Środowiska. Vol. 22 (2). Nr 60 p. 188-207.

Vogt N., Schuppener B., WeissenBach A., GajewsKa B., KŁosIŃSKI B. 2006. Podejścia obliczeniowe stosowane w Niemczech w projektowaniu geotechnicznym według Eurokodu 7-1 [Design approaches of EC 7-1 for geotechnical verifications used in Germany]. Inżynieria i Budownictwo. Nr 6. Warszawa. PZITB p. 326-330.

WYSOKIŃSKI L. 2005. Podstawy projektowania geotechnicznego [Basis of geotechnical design]. XX Ogólnopolska Konferencja Warsztat Pracy Projektanta Konstrukcji. Wisła - Ustroń. Kraków. PZITB p. 35-70.

Wysokiński L., KotLICKI W., GoDLEWSKI T. 2011. Projektowanie geotechniczne według Eurokodu 7. Poradnik [Geotechnical design according to Eurocode 7. Guide]. Warszawa. Dział Wydaw. ITB. ISBN 978-83-249-4831-4 pp. 286.

\section{Andrzej OLCHAWA, Andrzej ZAWALSKI \\ Porównanie projektowania fundamentów bezpośrednich na podstawie Eurokodu 7 i Polskiej Normy}

\section{STRESZCZENIE}

Słowa kluczowe: Eurokod 7, grunty spoiste, fundamenty bezpośrednie, nośność podłoża gruntowego, projektowanie geotechniczne

Wykonano obliczenia nośności podłoża spoistego na podstawie PN-B-03020:1981P i Eurokodu 7. Do obliczeń wg Eurokodu 7 przyjęto zmodyfikowane przez autorów parametry wytrzymałościowe gruntu spoistego: wytrzymałość na ścinanie w warunkach bez odpływu $c_{u}$, efektywną spójność $c^{\prime}$ i efektywny kąt tarcia wewnętrznego $\phi^{\prime}$. Wartości tych parametrów zależą od parametru wiodącego stopnia plastyczności $I_{L}$.

Wykonano obliczenia nośności podłoża dla dwóch stóp fundamentowych o wymiarach $B \times L=2,0 \times 3,0 \mathrm{~m}$ i 1,5 $\times 2,0 \mathrm{~m}$ oraz jednej ławy fundamentowej 2,0 $\times 14,0 \mathrm{~m}$. Obliczoną nośność podłoża wg EC 7 zredukowano mnożąc przez współczynnik $\alpha=0,87$ celem uwzględnienia stosowanych różnych współczynników obciążeń w Polskich Normach i Eurokodach. Przeprowadzone analizy obliczeń wykazały porównywalne nośności podłoża niezależnie od przyjętej normy EC 7 i PN dla stóp fundamentowych. Natomiast we wszystkich analizowanych przypadkach nośność ław fundamentowych obliczona wg Eurokodu 7 była większa od obliczonej wg PNB-03020:1981P. Przyczyną są różnice w wartościach i sposobie uwzględniania częściowych współczynników bezpieczeństwa oraz różnice $\mathrm{w}$ wartościach współczynników kształtu uwzględnianych we wzorze na całkowitą wartość oporu granicznego podłoża gruntowego. 